\title{
From Charity to Development: \\ Christian International Health \\ Organizations, 1945-1978
}

\author{
Walter Bruchhausen
}

\section{Introduction}

W ith the exception of the Red Cross, the history of non-governmental international organizations in the field of health has found far less attention than intergovernmental organizations and national nongovernmental organizations (NGOs). Globally acting non-governmental organizations used to be initiated by transnational movements constituted of such nationally organized social groups as trade unions, political parties, academic societies or religious bodies. This article will demonstrate how national NGOs like the Christian organizations Misereor and Bread for the World (Brot für die Welt) that were founded in Germany in 1958/59 could impact and even trigger the development of international NGOs working in health. It is argued that between the late 1950s and the 1970s these German organizations led the way in reconceptualizing faith-based aid work as a developmental issue, rather than a matter of charity and missionary activity. These organisations became models for similar organizations in other European and North American countries. 1 Their example was also followed by organizations at the international level devoted to health and development, namely Medicus Mundi (International Organization for Medical Cooperation) in 1963, CIDSE (Coopération internationale pour le développement socio-economique) in 1967 and the CMC (Christian Medical Commission of the World Council of Churches in Geneva) in 1968. The article concludes that the place of national and international Christian organisations may have been neglected in accounts of the processes that culminated in the Alma-Ata Declaration of 1978.

1 For example Fastenopfer and Brot für Brïder in Switzerland in 1961 and Catholic Relief Services in the USA, which was founded in 1943 but reshaped in this period. For the latter see Eileen Egan, Catholic Relief Services: The Beginning Years (New York: Catholic Relief Services, 1988). 


\section{The History of Christian Health Care Worldwide before 1945}

In early historical research Christian missions, when they were mentioned, were simply treated as part of the colonial health care system. Those who looked at disease control campaigns saw the role of missions as negligible ${ }^{2}$ while those who conducted research into the place of medicine as a 'tool of empire' simply conflated missions with the colonial authorities. ${ }^{3}$ The exception was the work of Terence Ranger in his seminal study of Southern Rhodesia ${ }^{4}$ and later studies followed his lead in looking at differing aspects of missionary medicine, including its geographical spread beyond the centres of colonial administration, its often difficult relationships with colonial and local authorities, how far it focused on individual care rather than public health and its emphasis on education and training. ${ }^{5}$ Similarities and oppositions between colonial and missionary medicine were highlighted and disputed, as the majority of research work consisted of case studies of single hospitals or mission societies with their own peculiar conditions. A monograph on the medical missionary movement in general ${ }^{6}$ and a collected volume on medical missions ${ }^{7}$ have been published, but nearly all of the studies cover the time before 1945. The history of the medical missions after the Second World War has yet to be written. The few studies of mission hospitals for the period after the end of the Second World War generally take the form of microstudies that integrate the larger context of altered international and national conditions in their analysis, but do not focus on them. ${ }^{8}$ Therefore any historical approach to this international level of Christian health work can only be a first attempt to sketch some major changes brought by decolonization and the

2 Cf. e.g. the contributions in Epidemics and Ideas: Essays on the Historical Perception of Pestilence, ed. Terence O. Ranger and Paul A. Slack (Cambridge: Cambridge University Press, 1992).

3 E.g. Megan Vaughan, Curing their Ills. Colonial Power and African Illness (Cambridge: Polity Press, 1991).

4 Terence O. Ranger, "Godly Medicine: The Ambiguities of Medical Mission in Southeastern Tanzania, 1900-1945," Social Science \& Medicine 15B (1981): 262. Abbreviated version in The Social basis of health and healing in Africa, ed. Steve Feierman and John M. Janzen (Berkeley: University of California Press, 1992), pp. 256-82.

5 Nancy R. Hunt, Colonial Lexicon of Birth Ritual, Medicalization, and Mobility in the Congo (Durham: Duke Univiversity Press 1999); Mike Jennings, "This Mysterious and Intangible Enemy': Health and Disease Amongst the Early UMCA Missionaries," Social History of Medicine 15 (2002): 65-87; Walter Bruchhausen, "Medicine between Religious Worlds. The Mission Hospitals of South-East Tanzania during the 20th Century," in From Western Medicine to Global Medicine. The Hospital Beyond the West, ed. Mark Harrison, Margaret Jones, and Helen Sweet (Hyderabad: Orient Black Swan, 2009), 262-93.

6 Christoffer Grundmann, Sent to heal!: Emergence and development of medical missions (Lanham/Md: University Press of America, 2005).

7 David Hardiman, ed., Healing Bodies, Saving Souls: Medical Missions in Asia and Africa, (Amsterdam: Rhodopi, 2006).

8 E.g. Pascal Schmid, "Medicine, faith and politics in Agogo. A history of rural health care in Ghana, ca 1925 to 1980 " (PhD diss., Basel, 2013). 
emergence of the development discourse. As will be shown, the recent WHO-related historiography of the pathways to Primary Health Care contains more on the role of the Christian Medical Commission, its experts and the projects of its institutional members than the historiography of mission medicine so far.

The changes in the twentieth-century to be analysed here must be seen against the background of the long and complex history of Christian health care. Since different from Greek and Roman antiquity where the medical profession was a profitable business - helping the sick is an explicit obligation of the New Testament institutionalised services for this group in need became a characteristic feature of Christian organisations from late antiquity onwards. Bishops, religious orders, brotherhoods and devote individuals founded hospitals that - like similar institutions in the contemporary Islamic world - cared for the diseased poor, too. Contributing to legitimizing European expansion, health care also became part of the modern evangelizing mission to countries outside Europe and America to the extent that sometimes the medical mission became increasingly separated from the religious one. ${ }^{9}$ Mission doctors, by their professional standing, were far less subordinate to mission societies and religious congregations than nursing sisters had been. ${ }^{10}$ In the China mission of the late nineteenth-century, for example, doctors often received more financial support from the local population than from the mission society at home. ${ }^{11}$ Local interest in Western medicine, science and education was often greater than curiosity about Western religion, and this made health care the most respected part of Christian missions.

It was certainly the case that for many towns in Southern China and rural areas in South Asia and Africa, Christian institutions were the main entry point for Western medicine. The missions began with medical education and even medical schools for Chinese students, sent West Africans for medical studies to Europe and opened training facilities for nurses and paramedics in all parts of the world. These activities gave rise to international societies and journals and increasingly influenced the medical and public understanding of health care worldwide. ${ }^{12}$

9 Edward V. Gulick, Peter Parker and the Opening of China (Cambridge/MA: Harvard University Press, 1973).

10 Chi-Min Wang and K. Chimin Wong, Lancet and Cross. Biographical Sketches of fifty Pioneer Medical Missionaries in China (Shanghai: Council on Christian Medical Work, 1950).

11 Cf. the annual financial reports in Report of the Tungkun Medical Missionary Hospital in connection with The Rhenish Missionary Society for the year 1893 [-1898], ed. Tungkun Medical Missionary Hospital (Hongkong: "China Mail" Office, 1894 [-1899]).

12 E.g. The China medical missionary journal (Shanghai) since 1887 and Medical Missionary (Philadelphia) since 1927. 


\section{Christian Health Care and Decolonization after 1945}

This pattern of health care by Christian institutions was dominant until decolonization began after 1945 and picked up pace in the 1950s. Christian medical care in colonized regions had been mainly provided by missionary societies from a range of Western countries, was usually (though not exclusively) focused on individual therapy, and routinely kept a distance from colonial administrations. Even where missionary doctors participated in some governmental health care activities such as training of health workers, disease control campaigns, vaccination schemes or mother and child health programmes they did not regard themselves as part of the colonial health care system. In 1919 Pope Benedict XV cautioned Catholic missionaries not to engage in overly close relationships with colonial administrations which might lead to their pursuing 'the interests of their terrestrial homeland [patria] instead of with those of their homeland in heaven'. His admonition ended with the order that they 'Remember that your duty is not the extension of a human realm [imperium], but of Christ's! ${ }^{13}$

The period of the 1950s and early 1960s brought several major changes to this established pattern of expatriate mission doctors and nurses running mission hospitals with support from their own congregations and friends at home. These changes can be understood under four distinct headings; churches and the secular world; aid organizations and the development discourse; local staff and independence movements; government budgets for development aid.

\section{Churches and the Secular World}

The years after 1945 were a time of major transformation for the Christian churches, worldwide and especially in Germany. The experiences of common enemies such as national socialism, communism and anti-religious forms of liberalism encouraged interdenominational and interreligious contacts as well as greater cooperation with those governments that were not hostile to religion or Christianity. Within the churches the growing influence of members who did not belong to the clergy, and renewed theological ideas led to changes in doctrine and discipline which improved the opportunities for an active role for Christian actors in many sectors of the modern world. The social sciences, which had often been regarded by both social scientists and theologians as attacks on religious authority, were now used as tools for reflection and re-organization in the churches, especially for long-term planning and provision of social services. Scientific medicine, modern education, democracy and liberal

13 Benedictus XV, "Maximum illud", [Apostolic Letter of 30 November 1919]. Acta Apostolicae Sedis 11 (1919): 440-55, here 446, quoted after the translation on http://www.who.int/global health histories/seminars/nairobi03.pdf(7 August 2014). 
economics were no longer regarded with scepticism or as threatening Christian order and tradition. Thus the 'civilizing mission' of Western societies, which had sometimes been seen as at odds with the 'proselytizing mission' of the churches, was now fully accepted in the modernization paradigm by missionaries. ${ }^{14}$ Humanizing societies, understood as introducing a mix of traditional Christian and modern values, not the head count of baptisms, became the dominant calling for Christian overseas work.

\section{Aid Organizations and the Development Discourse}

The very recent European experience of hunger and international relief, the Christian revival after the Second World War, and the ample flow of information about the seemingly devastating situation in many non-Western countries combined by the end of the 1950s to drive a sense in the churches of Europe that a key role for them was in tackling want. This seems to have been particularly acute in West Germany which, having itself been rescued from starvation and devastation by charity parcels from Care and the European Recovery Program (Marshall Plan), was by this time enjoying a new wealth as well as the liberty to organize church life denied under the Nazi regime. The first nationwide collections in both the Catholic and in the Protestant churches of Germany for the explicit intention of relieving 'hunger and disease' were made during lent and advent, respectively, in 1959. They resulted in the unexpectedly large sum of more than 50 million Marks, an amount that exceeded the recently introduced budget for international aid granted by the West German parliament. As a result, two new aid organizations were created to deploy these resources, Catholic Misereor and Protestant Bread for the World.

The distribution of these enormous funds immediately became a contested issue. On the Catholic side a debate took place in print between the clerical proponents of a classical evangelising mission and charitable work for the hungry and sick and those more influenced by the social science theories of the period who advocated a new type of support for investment in development. ${ }^{15}$ Led by a prelate, the head of Misereor Monsignore Gottfried Dossing (1906-1997), the latter started to dominate the debate. In 1959 the bishops' commission for distributing the donations had outlined the distinction it now made between 'direct aid by buying and donating medicines and medical equipment and sending doctors and nurses' and 'aid for selfaid comprising a) direct improvement of the health situation by educating and advising the population for better and more hygienic ways of living and eating, $b$ )

14 Klaus Fiedler, Christianity and African culture. Conservative German Protestant missionaries in Tanzania, 1900-1940 (Cologne: Brill, 1996).

15 Sylvie Toscer, Les catholiques allemands à la conquête du développement (Paris: Édition L'Harmattan, 1997). 
direct improvement of health care by constructing and enlarging hospitals, dispensaries, maternities etc., c) indirect improvement of health care by educating and training doctors and nurses (courses for nurses, constructing and enlarging nursing schools)'. ${ }^{16}$ The contested questions were whether 'structural aid' instead of 'direct aid' complied with the wording of the call for donations and thus the intentions of the donors and how the warning of pope Pius XII was to be interpreted. The pope had insisted that missionaries should only take on such tasks which are 'easy to perform and directly effective. ${ }^{17}$ Dossing stuck to his option for 'structural aid' and argued the pope's warning meant that other tasks, i.e. more difficult and long-term ones, should be fulfilled by lay members of the church, not the missionaries belonging to the clergy.

Misereor therefore became a developmental organization for 'structural aid' and not one for immediate assistance such as delivering medicines and food. This broader focus on relieving poverty, which was shared by the Protestant organization, Bread for the World, tried to make health care part of integrated developmental schemes. Epidemiological statistics replaced the missionaries' perception of local illness as the starting point of aid in health care. Non-medical factors for improved health, such as education and agriculture, were emphasised. This broad integrative development approach meant a greater focus on the prevention of ill-health and a new role for institutes for medical mission as technical agencies in health care.

\section{Local Staff and Independence Movements}

From the late nineteenth-century onwards locals trained in western medicine had taken on roles in Chinese and Indian hospitals and increasingly came to dominate their staff, but they were usually in subordinate positions to Europeans who tended to monopolise senior roles. In Africa this process only really gathered pace by the middle of the twentieth-century and was given fresh impetus as the continent's nations emerged in the post-colonial period, particularly when the new governments of these nations saw the permanent presence of Western health personnel as a nuisance and an embarrassing reminder of the recent past. These changes had two major consequences for Christian aid as well as for foreign governmental aid. First, Western medical personnel were only welcomed in Asia and Africa where they had special skills or particularly high qualifications e.g. in public health, health education, midwifery or anaesthesia. Secondly, the need for high quality local graduates to take

16 Anhang 4 zum Protokoll der Sitzung der Bischöflichen Kommission [Attachment 4 to the minutes of the meeting of the episcopal commission], 11.12.1959, MAA (Misereor Archive Aachen) Bischöfliche Kommission Sitzungen Protokolle 1959-1963.

17 Protokoll der 2. Sitzung des Beirats [Minutes of the 2 nd meeting of the advisory board], 18.1.1960 in Köln (Cologne), MAA Misereor Beirat Sitzungen, Protokolle 1959 bis 1974. 
on medical degrees in order to populate the medical services of post-colonial nations became urgent.

The German Catholics' initiative for foreign students, the Katholischer Akademischer Ausländerdienst/KAAD [Catholic Service to Academic Foreigners] founded in 1958, immediately focused on this need. Three quarters of its first batch of students that were supported by grants from Misereor consisted of future health professionals, the others being social and agricultural scientists. ${ }^{18}$ The first institution of higher education financed by Misereor was the Christian Medical College in Bangalore/India. ${ }^{19}$ Subsequently a medical college in Liberia was discussed, funding to support a university hospital in Congo was agreed and proposals were drawn up to do the same in Vietnam. ${ }^{20}$ Provisions were also made for European medical faculties, first in Pamplona and later in Rome, that were devoted to the medical education of students from overseas. ${ }^{21}$ Medical education became a major part of Christian 'development aid' which ensured that a considerable number of senior health professionals in post-colonial nations were trained in ways that were tinged with Christian messages.

\section{Government Budgets for Development Aid}

Another major change for church work in health was the introduction of budgets for development aid in all the Western states many of which had not been colonial powers before. Part of the motive for this was the fight against communism for which the churches were seen as likely allies. ${ }^{22}$ As the Western governments themselves did not have sufficient foreign partners for projects on the ground, the Christian organizations' turn from charity to development made them suitable partners for spending the funds. In West Germany the new Ministry of Development Cooperation, founded in 1961, used resources previously received from the Marshall Plan for development aid, as repeatedly demanded by Eisenhower and MacMillan since $1958 .^{23}$ Soon grants from this budget were also given to both major German

18 Bewilligung [Approval] 6.11.1959, MAA 510-0/1 Stipendien KAAD.

19 Protokoll der Sitzung der Bischöflichen Kommission [Minutes of the meeting of the episcopal commission], 11.12.1959, MAA Bischöfliche Kommission Sitzungen Protokolle 1959-1963.

20 Protokolle der 23. und 29. Sitzung des Beirats [Minutes of the 23rd und 29th meeting of the advisory board], 5.7.1963 und 18.2.1965, MAA Misereor Beirat Sitzungen, Protokolle 1959 bis 1974.

21 Protokolle der 16. und 31.-33. Sitzung des Beirats [Minutes of the 16th and 31st to 33rd meeting of the advisory board], 11.1.1962, 14.10.1965, 8.2.1966 bzw. 16.5.1966, MAA Misereor Beirat Sitzungen, Protokolle 1959 bis 1974.

22 Friedhelm Raden, Christliche Hilfswerke im Kalten Krieg (Herbolzheim: Centaurus, 2000).

23 Wolfgang Rieger, Wirtschaftswunder für farbige Völker? Deutschland und die Entwicklungshilfe (Hamburg: Rütten \& Loening, 1961), 16. 
churches which made up 50\% of their aid in these projects. ${ }^{24}$ Internal and external communications of the Ministry emphasised that health was addressed in a third of the development projects of the churches and thus the churches came only second to the state in German international health work. ${ }^{25}$ This financial cooperation, however, was much contested inside and outside the churches as clerics were concerned about compromising their independence in development work, and opponents of Christianity feared an increased influence of religion. ${ }^{26}$

In responding to these changes and new opportunities Christian churches in Europe began to see the advantages in, and need for new, international organizations to coordinate activities among the religious institutions of the continent in the sectors of health and development. The outcome of these processes was the foundation of Medicus Mundi Internationalis, CIDSE, and the World Council of Churches Christian Medical Commission in the 1960s.

\section{The Christian IHOS}

On the Catholic side Medicus Mundi Internationalis (International Organisation for Medical Cooperation) was founded by West European organizations and individuals engaged in health care within 'developing countries'. Set up in 1962 at the headquarters of Misereor in Aachen, its first president was the German medical doctor and specialist in tuberculosis Heinrich Jentgens. ${ }^{27}$ Its member organisations or national branches had been founded by quite different individuals and bodies. In the Netherlands, where Catholics were a large minority distrusted by Calvinist government circles, it was started by doctors' associations working in international health since 1957. In Belgium, where at the time Catholicism came close to a national religion, Caritas Catholica Belgica (the national Catholic humanitarian organization)

24 Karl Osner, Die entwicklungspolitische Zusammenarbeit der Bundesregierung mit den christlichen Kirchen in der Bundesrepublik Deutschland. Vortrag im Campo Santo, Rom April 1979 (Rom: KAEF, 1979).

25 Der Bundesminister für Jugend, Familie und Gesundheit, Gesundheitsbericht (Bonn: Kohlhammer, 1971), 170; Scheiber, BMZ Referat I B 6, Anlage zum Vermerk vom 6.8.1970, BArch (Bundesarchiv/Federal Archive Koblenz) B213/4960 1970/71 Fragen des Gesundheitswesens, III A/7-T9010 Gesundheitspolitik in der BRD (Gesundheitsbericht); Entwurf für den AwZ [Ausschuss für wirtschaftliche Zusammenarbeit] Vermerk „Veränderungen in der Projektpolitik im Bereich der Gesundheitshilfe" (Februar 1975), BArch B213/4990 Allg. und Grundsatzfragen der Gesundheitshilfe [305/T9000], AwZ-305T9000 Heft 1.

26 Gerhard Brenneke, „Hier gibt es nur ein klares Nein“, in: Christian Berg (ed.), Brot fuir die Welt. Dokumente, Berichte, Rufe (Berlin: Lettner, 1962), 179-183 Rieger, Wirtschaftsuninder, 137-38.

27 Bericht über die Sitzung des Sonderausschusses am 17.12.1963 im Missionsärztlichen Institut Würzburg [Report on the meeting of the special commission 17.12.1963 in the Medical Missionary Institut Würzburg], MAA 1991/1 HGF Missionsärztliches Institut 1963-1969. 
founded the branch with the director of an institute of tropical medicine as its head. The French branch counted a national minister and a number of professors among its founders while in mainly Catholic Austria former mission doctors organised Medicus Mundi. In the Rhineland of Germany, a Catholic doctors guild in close collaboration with the new 'development aid' experts in Catholic aid organizations, especially Misereor, combined with the federal ministry for development cooperation to set up the organization. In Spain medical specialists together with Jesuit priests founded Medicus Mundi in several largely independent regional branches, each with health projects of their own. The Irish organization was established at the initiative of the Medical Missionaries of Mary, a congregation of religious sisters. ${ }^{28}$ Pre-existing associations in other countries, some founded as early as the 1920s, joined as national or associate members. The Medical Mission Sisters (the Society of Catholic Medical Missions) and the Catholic Medical Mission Board (CMMB) in New York represented the USA. The Swiss medical missionary society (Schweizerischer Katholischer Missionsärztlicher Verein) joined in 1970 by founding the Swiss branch of Medicus Mundi as a non-denominational body. Doctors from Italy, Algeria and later Poland were represented as well.

During their first years the national branches and the international annual general assembly were busy in sending hundreds of health workers into Asia, Africa, Latin America and Oceania for between three and five years at a time. By 1966, however, the Secretary General Dobers was complaining that Medicus Mundi was mostly an office for recruiting these workers, while other 'goals, namely improving health [and the problem of] the dependence of medico-social assistance on the economic and cultural development of the countries [have been] largely neglected. ${ }^{, 29}$ According to the Secretary General there were too many hospitals and too much curative care. In response, by the late 1960s the annual general assembly began exploring options for more wide-ranging health strategies. ${ }^{30}$

28 Heinrich Jentgens, Kleiner geschichtlicher Überblick auf den Beginn von Medicus Mundi [Short historical overview on the beginnings of Medicus Mundi], in Medicus Mundi/International Organisation for Medical Cooperation, Profil, 7-11, MAA Box 1996/15 GW Medicus Mundi Internationalis 1972-1987.

29 GS Dobers at the 3rd International General Assembly, 21.5.1966, Monserrat, according to E. Widmer and M. Manciaux, Die Aktivitäten von MMI, in Medicus Mundi/International Organisation for Medical Cooperation, Profil, 12-19, here 14, MAA Box 1996/15 GW Medicus Mundi Internationalis 1972-1987.

30 Edgar Widmer, MMI history and philosophy [Reprint from 2003 of the address to the conference " 40 years of fighting global poverty by promoting health", Berlin, 24 October 2003], in: 50 years of Medicus Mundi International Network, 1963-2013 Looking back and ahead. Memories and insights by MMI presidents (Annex to the Annual Report 2012 of the Medicus Mundi International Network), 12-14; Medicus Mundi/International Organisation for Medical cooperation, ed. Documentation of the General Assembly, Amsterdam, 20-22 May 1977 (Aachen: General Secretariate of Medicus Mundi

International, n.d. [ca. 1977]), see: List of participants and Table I-III. 
But Medicus Mundi was not alone as an international organization established to coordinate European Catholic intervention in the health care of 'developing countries'. In 1965, at the end of the Second Vatican Council in Rome, the Catholic Church opened the way for cooperation with other churches and religions as well as secular institutions. The German Archbishop of Cologne Josef Cardinal Frings, who had played a key role in founding Misereor, initiated a meeting with the bishops of eight other national Catholic developmental organizations which were mostly financed by lent donations. This meeting paved the way for the foundation in 1967 of CIDSE (International cooperation for socio-economic development, since 1981 International cooperation for development and solidarity). This was designed to be distinct from Caritas Internationalis, the Catholic Church's humanitarian organization which was also active in the international health sector, but mainly for emergency aid. ${ }^{31}$ As with Medicus Mundi, the key health issue in the international meetings of CIDSE in the late 1960s became the departure from hospital-based curative care which was regarded as old-fashioned and an obstacle to comprehensive health services.

On the Protestant side two international consultations on international Christian health care took place in 1964 and 1967 in Tubingen, the old seat of the Deutsches Institut für Ärztliche Mission (German Institute for Medical Mission) which had been set up in $1906 .^{32}$ These consultations stated that the churches' health care hitherto had not been sufficiently oriented towards the needs of the poor and the majority of the populations. The traditional idea that illness was a consequence of individual sin and a sign of the presence of evil in the person was rejected in favour of a new view that the social or structural sin of gross inequality marginalised parts of the population and caused most ill-health. ${ }^{33}$ These theological, ethical and medical reflections lead to the foundation of the World Council of Churches Christian Medical Commission (CMC) with its headquarters in Geneva. The Christian Medical Commission was to become the most politically influential of the

31 Josef Teusch, „Zuerst: Eine Äußerung des Glaubens. Das Bischöfliche Werk, Misereor', seine Anfänge und seine Initialwirkung in die Weltkirche", in Die Ortskirche im Dienst der Weltkirche. Das Erzbistum Köln seit seiner Wiedererrichtung im Jahre 1825, ed. Norbert Trippen and Wilhelm Mogge (Cologne: J. P. Bachem, 1976), 200.

32 World Council of Churches, ed., The Healing Church: The Tiubingen Consultation 1964 (Geneva: World Council of Churches, 1965); World Council of Churches, ed., Health: Medicaltheological Perspectives. Preliminary Report of a Consultation held in Tübingen, Germany, Sept.1-8, 1967 (Geneva: World Council of Churches,1967).

33 Rainward Bastian, „Kirchliche Gesundheitsarbeit auf evangelischer Seite," in Entwicklungsziel Gesundheit. Zeitzeugen der Entwicklungszusammenarbeit blicken zurück, ed. Walter Bruchhausen, Helmut Görgen, and Oliver Razum (Frankfurt/M.: Peter Lang, 2009), 28-29. 
international Christian health organizations, in part through its contacts in the USA. $^{34}$

\section{The Shift to 'Community-Centred Health'}

By the end of the 1960s both Catholic and Protestant IHOs were well established, and grappling with similar issues. At the annual international general assembly of Medicus Mundi in 1969 a German Professor of Tropical Medicine Hermann Knüttgen, director of the university institute in Tubingen, challenged 'modern medicine' and complained about its interference with 'indigenous continuous development'. He was sure that 'markedly environment-conditioned diseases' could 'be reduced without special measures' by better preventive programmes and education. ${ }^{35}$ Moreover, he argued that 'the professional education of students from young nations at European medical faculties is far from ideal for the health service of their own countries' and was an advocate of a model from Tanzania for the 'formation and training of local assistants' in situ. In the same year John Harland Bryant published the seminal book Health of the Developing World which made similar arguments, and he was soon to become chairman of the CMC and director of Columbia University's school of public health, and later serve as a member of the US delegation in Alma Ata. ${ }^{36}$ The Director of the CMC, James McGilvray, also echoed these arguments in 1969 to a conference of the American Medical Association, ${ }^{37}$ as did the chairman of the Department of International Health at the

34 Carl E. Taylor, "What is different now?: A Christian Medical Commission's Role in Health Planning" (presentation at Johns Hopkins University, 2003). http://www.ccih.org/Christian Medical Commission's Role in Health Planning Taylor.ppt Accessed 23 August, 2013; Socrates Litsios, "The Christian Medical Commission and the Development of the World Health Organization's Primary Health Care Approach". American Journal of Public Health 94 (2004): 1884-93; Marcos Cueto, "The Origins of Primary Health Care and Selective Primary Health Care." American Journal of Public Health 94 (2004): 1864-74; Dan Kaseje, "The contribution of the Christian Medical Commission to health care in Africa in the post colonial era" (presentation at the WHO's initiative on Global Health Histories Meeting in Nairobi, February 6-8, 2006). Accessed 23 August, 2013. http://www.who.int/ global health histories/seminars/nairobi03.pdf.

35 Hermann Knüttgen, „Die Bedeutung der Medizin in der Entwicklungshilfe“ [,Place and Importance of Medicine in Development Aid'], 6th International General Assembly of MM Bensberg 7-8 June 1969, MAA 1991/1 HGF Medicus Mundi Sitzungen bis 1965, Generalvers. bis 1973.

36 John H. Bryant, Health \& the Developing World (Ithaca/NY: Cornell University Press, 1969).

37 Cited from China Health Care Study Group, ed., Health care in China. An Introduction (Geneva: Christian Medical Commission, 1978) 12. 
Johns Hopkins School of Public Health, Carl E. Taylor in an influential article on the future of the CMC. ${ }^{38}$

If the move away from hospital based personal care appeared to be the way forwards, the challenge of working out exactly what would replace it remained. Christian IHOs closely observed pioneering initiatives around the world. Perhaps the most famous and influential was set up in 1970 by Raj and Mabelle Arole in Jamkhed, Maharashtra. ${ }^{39}$ The CMC followed this project which sought to introduce new methods of communication, training, identifying and solving problems and which drew on methods pioneered by WHO and UNICEF. But the responses of certain national governments also drew the attention of the Christian IHOs in seeking the way forwards from the rejection of hospital based medicine. In 1972 the Christian Medical Commission appointed a group of medical and social scientists in Hong Kong to study the question 'What in the Chinese experience of rebuilding a health care system might be of value to communities in other cultures and social systems? ${ }^{30}$ The study group was composed of both Chinese and Anglophone experts from medical and non-medical disciplines and financed by the German Arbeitsgemeinschaft für Weltmission (Working Association for World Mission). It concentrated on China's experience of setting health-related national goals, reorganizing health care systems, tackling epidemic disease, controlling population size, approaching traditional and Western practices, and dealing with mental illness. This focus on national experiences grew throughout the 1970s. The annual general assemblies of Medicus Mundi discussed Putina/Peru, Gabon and Korea in 1973; Nepal, Malawi and Algeria in 1974; Niger, Panama and Zaire in 1975 and so on. ${ }^{41}$ They complemented these reports with speakers who had experience in the field. Ali Hassan Mwinyi appeared in 1974 as Health Minister for Tanzania (he would late serve as president), as did Dr A. Eberwein of the WHO. Another member of the latter, Dr D. Flahault spoke in 1975 and in the following year the then Health Minister of Tanzania, Leader Dominic Stirling, presented. He had been first an Anglican, and then a Catholic mission doctor.

The Christian IHOs seem to have concluded that centre and starting point were 'communities', as their mobilisation and participation were regarded as indispensable for sustainable success. The 'Concepts 1' document produced by Medicus Mundi in 1968 and edited by the Dutch professor H.A.P.C. Oomen stated that fundamental

38 Carl E. Taylor, "A Christian Medical Commission's Role in Health Planning". International Review of Mission 58 (1969): 181-94.

39 Pai D. Malgavkar, Rural health care: The Jamkhed Project (New Delhi: Centre for Policy Research, 1981).

40 John H. Bryant, Foreword to Health Care in China. An Introduction, by China Health Care Study Group (Geneva: Christian Medical Commission 1978), 7.

41 MAA 1991/1 HGF Medicus Mundi Sitzungen bis 1965, Generalvers. bis 1973; Medicus Mundi Internationalis Kommissionssitzungen 1974-1975; 1976-1977. 
to the mission in 'developing countries' was a commitment to 'improving [the] health of the community with its own co-operation'. 'Y2 Yet the word 'community' could be ambiguous and was as often used to name the target rather than the agent of health care. For several academic medical experts advising the churches, the terms 'community health' or 'community medicine' were better than 'public health, preventive medicine, or social medicine' for describing the necessary approach, defined as 'medicine of man in the aggregate'. ${ }^{43}$ According to William Foege, a director from the National Communicable Disease Center in Atlanta/Georgia, this approach went 'beyond the discussions of care of total man to care of total men'. Maximum care for the individual should be replaced by providing for 'the health needs of groups, communities, areas, countries, and regions'.

But by the early 1970s it was also clear that some engagement with national administrations and other IHOs was necessary too. In 1972 the 'First Asian Ecumenical Conference on the Role of Health in the Development of Nations' in Bangkok declared that 'As part of the health development program, we of the Church should strive to influence Governments and other interested medical bodies to provide better health care facilities and better conditions of living. ${ }^{44}$ As the headquarters of the World Council of Churches was located in Geneva the opportunities for the $\mathrm{CMC}$ to influence the $\mathrm{WHO}$ were especially frequent. Member church organizations also discussed appropriate strategies with senior civil servants and government officials back in Europe. The CMC had members from East and West Germany so it could even broker some exchange of experiences rare during the late Cold War. ${ }^{45}$

While Christian IHOs consulted widely on experiences elsewhere and were keen to draw on the successes and failures of others, they also acted. The $\mathrm{CMC}$ 'sponsored ... several experimental projects in health care delivery', the first of which was the 'Koje Do Project' in South Korea. ${ }^{46}$ This was conceived as 'a six-point project: a broad, community-centred health programme consisting of family planning, public health, and a scientifically controlled, sub-maximal curative medicine' coordinated with other local activities. ${ }^{47}$ This commitment was not uncontroversial as critics

42 3rd international general assembly of Medicus Mundi, 4.15.5. 1968, Viller la Ville/Belgium.

43 William H. Foege, "Community Medicine". Contact2 (1971): 1.

44 "First Asian Ecumenical Conference on the Role of Health in the Development of Nations", Bangkok December 1972 (Bangkok 1973), cited from L.K. Ding, preface to Health Care in China. An Introduction, by China Health Care Study Group (Geneva: Christian Medical Commission 1978), 10-11.

45 Anonymous, "Meeting of the CMC in Bad Saarow, German Democratic Republic, 1-8 April 1979," Contact 51 (1979): 9-14.

46 James C. McGilvray, "Short introductory note on J. R. Sibley, 'The Koje Do ProjectProgress and Problems"”. Contact Occasional Paper No. 5. (1971).

47 Sibley (1971) as in the previous FN, 2. 
argued that providing the best possible care for individuals in need and for the sick was a Christian duty too. Nevertheless it was clear that a direction had been set. Resources were to be focused on 'community' health and curative medicines were not to be the priority.

\section{Conclusion}

This article has explored some of the drivers of change in the approach to providing healthcare of European Christian organisations in the period after the Second World War. They moved from a hospital-based focus on curative medicine to communityfocused primary healthcare in the three decades or so after 1945. The reasons for this lay in their recent experiences both in Europe and also in decolonizing regions. As parts of Asia, Africa and elsewhere decolonized, the national states that emerged sought to assert their authority over the populations under their control. In this context, foreign missions that set their own agendas and delivered medical care to groups of their choice looked dangerously like the colonial past even where the missions had distanced themselves from administrators of the former European empires. Besides the preoccupation with sovereignty, priorities in these new nations tended towards ideas of development brought up in late colonialism. ${ }^{48}$ What had been on offer from many European mission societies earlier in the century was no longer welcomed in regions that were decolonizing. Asian and African governments no longer accepted charitably hospital work supervised by Europeans but demanded integration into the national health care system. Responsibility had to be handed over to nationals who often first needed to study or get further qualification. Due to the initial lack of academically educated staff and medical schools this had to be done by grants for Europe or supporting new colleges.

At the same time there was change in Europe. Christian churches in Germany were revitalized after the traumas of National Socialism and the Second World War and as the continent grew economically in the 1950s. The experience of recovery from starvation and the traumas of oppression and war in Europe bred an optimism that similar improvements could be achieved elsewhere. Rejection of the old missionary models led to a nationalisation of Christian overseas health work as responsibility for delivery shifted from foreign mission societies to national churches. It also meant searching for alternatives to the mission models of charitable services, and collaboration in development became the spirit of the age. Churches worked together in the West to pool ideas, resources and personnel and Christian IHOs were

48 Walter Bruchhausen, "From precondition to goal of development. Health and medicine in the planning and political conflicts of British Tanganyika Territory". In Developing Africa: Concepts and practices in twentieth century colonialism, edited by Joseph Hodge, Gerhard Hödl, and Martina Kopf, 207-221. Manchester: Manchester University Press, 2014. 
established as part of this phenomenon. European governments that had difficulties in finding suitable partners for their new 'development aid' in health granted considerable funds to the established services of the churches for developing health care. Soon and in most places, European mission societies no longer ran hospitals and other health services themselves but they and their Christian IHOs supported local churches and initiatives instead. These local actors were increasingly seen more as partners in development than as objects for aid. The result was a closer connection of the churches with local congregations and action groups. The outcome of these processes was not just a move to 'working for the people' on the part of European Christian organisations in delivering healthcare but also to 'working with the people' to do so.

By the end of the 1970s the emphasis on community participation in delivering healthcare, and also in assessing the effectiveness of that delivery, was enshrined in the Alma Ata Declaration made at the International conference on primary health care organised by WHO and the United Nations Children's Fund (UNICEF) in 1978. The shift from strongly paternalistic, even authoritarian sanitation policies of states, and particularly colonial states, to rights-based and participative health action became the official international programme. Histories that explore the origins of this declaration have recently pointed to the influence of Christian IHOs on Alma Ata in addition to national actors and UN agencies. ${ }^{49}$ The reasons, however, why and how they were engaged in the same debates and were concerned about similar issues, in the decades immediately before 1978, are not yet sufficiently understood. Future research might usefully explore what precisely Christian organisations like the CMC and Medicus Mundi had to offer to the origins of the Alma Ata Declaration..$^{50}$

Walter Bruchhausen is senior lecturer in medical history at the University of Cologne and RWTH Aachen University.

49 Litsios (2004) as in FN 34.

50 A good place to start would be "Non-governmental organizations and primary health care" (Position paper for the Conference of Alma Ata, Reprint). Contact 48 (1978): 8-10. 


\title{
References
}

\author{
Archives
}

Bundesarchiv/Federal Archive Koblenz (BArch)

Misereor Archive Aachen (MAA)

\section{Published sources}

Bastian, Rainward, "Kirchliche Gesundheitsarbeit auf evangelischer Seite", pp. 3-38 in Walter Bruchhausen, Helmut Görgen, and Oliver Razum Entwicklungsziel, eds, Gesundheit. Zeitzeugen der Entwicklungszusammenarbeit blicken zurück. Frankfurt, 2009.

V, "MaxiBenedictus Xmum illud", in Acta Apostolicae Sedis, 11 (1919), 440-55.

Bruchhausen, Walter, "Medicine between Religious Worlds. The Mission Hospitals of South-East Tanzania during the 20th Century" pp. 262-93 in Mark Harrison, Margaret Jones, and Helen Sweet, eds, From Western Medicine to Global Medicine. The Hospital Beyond the West. Hyderabad, 2009.

Bruchhausen, Walter, "From precondition to goal of development. Health and medicine in the planning and political conflicts of British Tanganyika Territory" in Joseph Hodge, Gerhard Hödl and Martina Kopf, eds, Developing Africa: Concepts and practices in twentieth century colonialism. Manchester, 2014.

Bryant, John H., Health \& the Developing World. Ithaca, 1969.

Bundesminister für Jugend, Familie und Gesundheit, Gesundheitsbericht. Bonn, 1971.

Christian Berg, ed., Brot für die Welt. Dokumente, Berichte, Rufe. Berlin, 1962.

China Health Care Study Group, eds, Health Care in China. An Introduction. Geneva, 1978.

The China medical missionary journal (Shanghai), from 1887.

Cueto, Marcos, "The Origins of Primary Health Care and Selective Primary Health Care." American Journal of Public Health 94 (2004), 1864-74.

Egan, Eileen, Catholic Relief Services: The Beginning Years. New York, 1988.

Feierman, Steve and John M. Janzen, eds, The Social basis of health and healing in Africa. Berkeley, 1992.

Fiedler, Klaus, Christianity and African culture. Conservative German Protestant missionaries in Tanzania, 1900-1940. Cologne, 1996.

Grundmann, Christoffer, Sent to heall: Emergence and development of medical missions. Lanham, 2005.

Gulick, Edward V., Peter Parker and the Opening of China. Cambridge/MA, 1973. 
Hardiman, David, ed., Healing Bodies, Saving Souls: Medical Missions in Asia and Africa. Amsterdam, 2006.

Hunt, Nancy R., Colonial Lexicon of Birth Ritual, Medicalization, and Mobility in the Congo. Durham, 1999.

Jennings, Mike, “This Mysterious and Intangible Enemy': Health and Disease Amongst the Early UMCA Missionaries", Social History of Medicine 15 (2002), 65-87.

Kaseje, Dan, The contribution of the Christian Medical Commission to health care in Africa in the post colonial era. Presentation at the WHO's Global Health Histories Meeting 2006, http://www.who.int/global_health_histories/seminars/nairobi03.pdf, accessed 23 August 2013.

Litsios, Socrates, "The Christian Medical Commission and the Development of the World Health Organization's Primary Health Care Approach", American Journal of Public Health 94 (2004), 1884-93.

Malgavkar,, Pai D. Rural health care: The Jamkhed Project. New Delhi, 1981.

McGilvray, James, "Short introductory note on J. R. Sibley, 'The Koje Do Project Progress and Problems"', Contact Occasional Papers, 5 (1971).

Medical Missionary (Philadelphia), from 1927.

Medicus Mundi/International Organisation for Medical cooperation, ed., Documentation of the General Assembly, Amsterdam, 26-22 May 1977. Aachen, 1977.

"Meeting of the CMC in Bad Saarow, German Democratic Republic, 1-8 April 1979", Contact 51 (1979), 9-14.

"Non-governmental organizations and primary health care", Contact 48 (1978), 810.

Osner, Karl, Die entwicklungspolitische Zusammenarbeit der Bundesregierung mit den christlichen Kirchen in der Bundesrepublik Deutschiand. Rom, 1979.

Raden, Friedheim, Christliche Hilfswerke im Kalten Krieg. Herbolzheim, 2000.

Ranger, Terence O., "Godly Medicine: The Ambiguities of Medical Mission in Southeastern Tanzania, 1900-1945”, Social Science \& Medicine 15B (1981), 262.

Ranger, Terence O. and Paul A. Slack, eds, Essays on the Historical Perception of Pestilence. Cambridge, 1992.

Rieger, Wolfgang, Wirtschaftswunder für farbige Völker? Deutschland und die Entwicklungshilfe. Hamburg, 1961.

Schmid, Pascal, Medicine, faith and politics in Agogo. A history of rural health care in Ghana, ca 1925 to 1980. PhD, Basel, 2013.

Taylor, Carl E., "A Christian Medical Commission's Role in Health Planning", International Review of Mission 58 (1969), 181-94.

Carl E. Taylor, What is different now?: A Christian Medical Commission's Role in Health Planning. Presentation at Johns Hopkins University, 2003, 
www.ccih.org/Christian_Medical_Commission's_Role_in_Health_Planning Taylor.ppt Accessed 23 August, 2013.

Toscer, Sylvie, Les catholiques allemands à la conquête du développement. Paris, 1997. Teusch, Josef, "Zuerst: Eine Äußerung des Glaubens", in Norbert Trippen and Wilhelm Mogge, eds, Die Ortskirche im Dienst der Weltkirche. Cologne, 1976.

Tungkun Medical Missionary Hospital, Report of the Tungkun Medical Missionary Hospital in connection with The Rhenish Missionary Society for the year 1893. Hong Kong, 1894.

Vaughan, Megan, Curing their Ills. Colonial Power and African Illness. Cambridge, 1991.

Wang, Chi-Min and K. Chimin Wong, Lancet and Cross. Biographical Sketches of fifty Pioneer Medical Missionaries in China. Shanghai, 1950.

World Council of Churches, ed., The Healing Church: The Tübingen Consultation 1964. Geneva, 1965.

World Council of Churches, ed., Health: Medicat-theological Perspectives. Preliminary Report of a Consultation held in Tübingen, Germany, Sept.1-8, 196\%. Geneva, 1967. 